\title{
LESSON STUDI SEBAGAI UPAYA MENINGKATKAN AKTIVITAS BELAJAR MAHASISWA
}

\section{Darwanto *)}

\begin{abstract}
Improving the quality of education in Higher Education can be started by improving the quality of lecturers in teaching and professional behavior. One of the priority education issues is the quality of education, especially the quality of learning. From the various conditions and potentials, the efforts that can be made to improve the quality of learning in Higher Education is to develop student oriented learning and facilitate it in learning. One of the models of educator profession development through collaborative and sustainable learning is Lesson Study. Through the stages in the lesson design can enhance student learning activities.
\end{abstract}

Keyword: learning activity, lesson study

\section{PENDAHULUAN}

Dalam rangka meningkatkan mutu pendidikan di Perguruan Tinggi diperlukan upaya yang serius untuk meningkatkan kualitas para dosen. Walaupun hal tersebut bukan satu-satunya pihak yang memiliki peran penting untuk meningkatkan mutu pendidikan di Perguruan Tinggi, seorang dosen tetap memiliki peran yang paling besar karena inovasi serta peningkatan mutu pendidikan dapat dimulai di kelas melalui inovasi dalam proses pembelajaran.

Peningkatan mutu pendidikan di Perguruan Tinggi dapat dimulai dengan meningkatkan mutu dosen dalam mengajar dan berprilaku profesional. Berbagai penataran dan pelatihan dosen menjadi salah satu bentuk dari upaya tersebut. Akan tetapi, seringkali hal itu tidak membekas dalam keseharian aktivitas dosen. Hal inilah yang mendasari perlunya perbaikan yang menitikberatkan kepada kondisi riil di lapangan, mulai dari kondisi di kelas, lembaga, dan dosen itu sendiri. Upaya perbaikan senantiasa dilakukan sehingga upaya tersebut mampu dalam menyelesaikan permasalahan-permasalahan dalam pendidikan, terutama pembelajaran di kelas.

Salah satu permasalahan pendidikan yang menjadi prioritas adalah masalah kualitas pendidikan, khususnya kualitas pembelajaran. Dari berbagai kondisi dan potensi yang ada, upaya yang dapat dilakukan untuk peningkatan kualitas pembelajaran di Perguruan Tinggi, yaitu mengembangkan pembelajaran yang berorientasi pada mahasiswa dan memfasilitasinya dalam pembelajaran.

Cara pandang terhadap mahasiswa dalam hal ini dapat disebut peserta didik yang 
dahulu sebagai objek kini berangsur-angsur berubah menjadi subjek dari pembelajaran. Dengan demikian, dosen dalam hal ini dapat disebut pendidik harus mampu berinovasi dan terus mengembangkan pembelajarannya. Davies dalam Rusman (2014:229) mengemukakan bahwa "salah satu kecenderungan yang sering dilupakan, yaitu melupakan bahwa hakikat pembelajar an adalah belajarnya peserta didik dan bukan mengajarnya pendidik". Dari penjelasan tersebut, dapat dikatakan bahwa yang menjadi pusat perhatian pembelajaran, yaitu peserta didik bukan pendidik. Oleh karena itu, pada pembelajaran peserta didik dituntut aktif.

Seiring dengan perkembangan ilmu pengetahuan dan teknologi, perlu dilakukan pengembangan kualitas tenaga pendidik dan kualitas pembelajaran. Salah satu model pembinaan dan pengembangan tenaga pendidik adalah melalui model lesson study.

\section{PEMBAHASAN}

Lesson study dikembangkan per -tama kali di Jepang yang dilaksanakan sebagai program pengembangan profesional pendidik. Lesson Study merupakan suatu model pembinaan profesi pendidik melalui pengkajian pembelajaran secara kolaboratif dan berkelanjutan, berdasarkan prinsipprinsip kolegalitas yang saling membantu dalam pembelajaran untuk membangun komunitas belajar.
Hendayana (2007:10) menyebutkan bahwa Lesson study merupakan model pembinaan profesi pendidik melalui pengkajian pembelajaran secara kolaboratif dan berkelanjutan berlandaskan prinsipprinsip kolegalitas dan mutual learning dengan tujuan membangun komunitas belajar. Lesson study merupakan suatu rangkaian kegiatan dalam pembelajaran dan bukan merupakan metode atau strategi pembelajaran. Lesson study dapat menggunakan atau menerapkan berbagai metode ataupun strategi pembelajaran yang sesuai dengan situasi, kondisi, dan permasalahan yang dihadapi pendidik.

Meurut Lewis, Perry dan Murata dalam Susilo dkk (2011:3), dalam melaksanakan Lesson study pendidik secara kolaboratif 1) mempelajari kurikulum dan merumuskan tujuan pembelajaran dan tujuan pengembangan peserta didiknya (mengembangkan kecakapan hidupnya; 2) merancang pembelajaran untuk mencapai tujuan; 3) melaksanakan dan mengamati suatu research lesson; dan 4) melakukan refleksi untuk mendiskusikan pembelajaran berikutnya.

Menurut Slamet (2010:59) Lesson Study merupakan kegiatan terus menerus yang tiada henti dan suatu upaya untuk mengaplikasikan prinsip-prinsip dalam Total Quality Management, yakni memperbaiki proses dan hasil pembelajaran siswa secara terus-menerus, berdasarkan data. Lesson 
Study merupakan kegiatan yang dapat mendorong terbentuknya sebuah komunitas belajar (Learning society) yang secara konsisten dan sistematis melakukan perbaikan diri (Saito et al, 2015).

Tujuan lesson studi dalam Susilo dkk (2011:17) menyebutkan bahwa Lesson study memberikan manfaat bagi pendidik di antaranaya sebagai berikut: 1) mengurangi keterasingan pendidik (dari komunitasnya) dalam merencanakan dan pelaksanaan pembelajaran dan perbaikannya;

2) buku ajar.

membantu pendidik untuk mengobservasi dan mengkritisi pembelajarannya; memperdalam pemahaman pendidik tentang materi pelajaran, cakupan dan urutan kurikulum; 4) membantu pendidik memfokuskan bantuannya pada seluruh aktivitas belajar peserta didik; 5) meningkatkan mutu pendidik dan mutu pembelajaran yang pada akhirnya berakibat pada peningkatan mutu lulusan (peserta didik); 6) memungkinkan pendidik memiliki banyak kesempatan untuk membuat bermakna ide-ide pendidikan dalam praktik pembelajarannya sehingga dapat mengubah perspektif tentang pembelajaran, dan belajar praktik pembelajaran dari perspektif peserta didik; dan 7) memperbaiki praktik pembelajaran di kelas; 8) meningkatkan keterampilan menulis karya tulis ilmiah atau Langkah-langkah penerapan lesson studi di Indonesia menurut Susilo (2011:35) meliputi 3 tahap, yaitu tahap Perencanaan (Plan), tahap pelaksanaan (Do), tahap pengamatan dan refleksi (See). Siklus pengkajian pembelajaran dilaksanakan dalam tiga tahap, seperti dalam Gambar berikut ini.

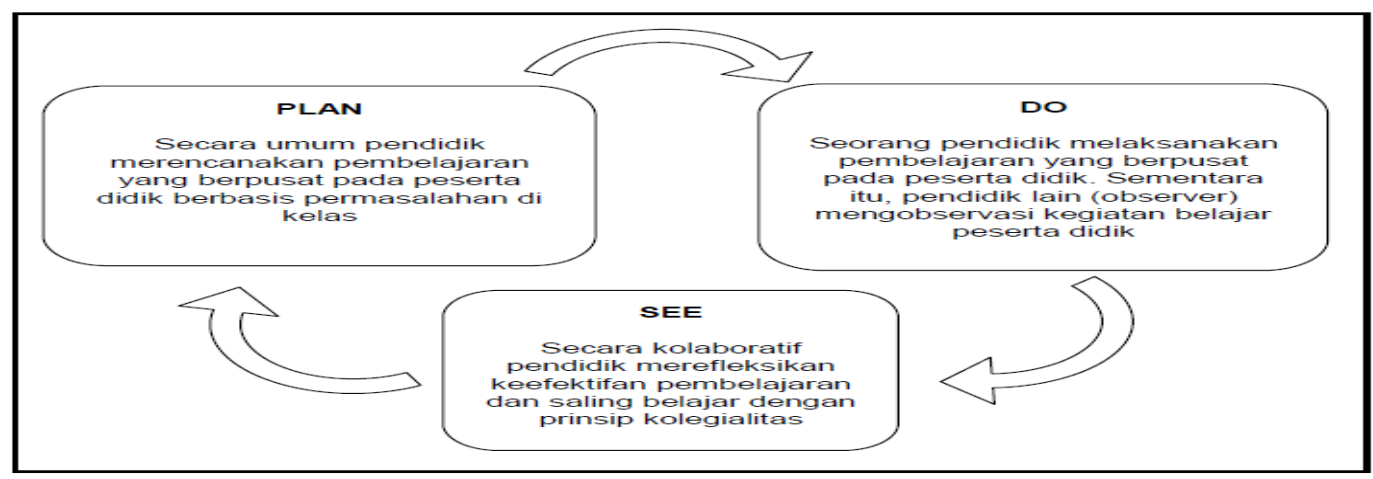

Sumber: Susilo dkk (2011)

Gambar tersebut merupakan siklus see terus sampai dengan pertemuan pengkajian pembelajaran di Indonesia, siklus berikutnya sesuai dengan rencana tersebut pada setiap tahapnya terus berulang, pembelajaran yang dilakanakan pada lesson dimulai dengan tahap plan, kemudian do, lalu studi. 
Tahap perencanaan (Plan), tahap perencanaan ini sekelompok pendidik secara bersama-sama (kolaboratif) menyusun rencana pembelajaran yang akan dilaksanakan, dengan semua perangkat pembelajaran yang diperlukan (Lembar Kerja, Instrumen untuk evaluasi, media, serta perangkat lainnya). Tahap merencanakan ini. Setiap anggota kelompok LS mencurahkan pikiran untuk menghasilkan skenario pembelajaran yang baik atau dengan strategi yang tepat dan operasional (sesuai dengan kondisi dan sistuasi siswa, sekolah dan sarana pendukungnya). Perencanaan dilakukan secara kolaboratif berdasarkan permasalahan di kelas untuk mengembangan model pembelajaran yang berpusat pada siswa melalui hands-on \& minds-on activity, daily life, and local materials. Secara umum kegiatan plan berupa penggalian akademik, perencanaan pembelajaran dan penyiapan alat-alat. Perencanaan pembelajaran dilakukan dengan memperhatikan tujuan pembelajaran dan karakteristik serta perkembangan peserta didik, yang dilkukan secara koligeal dan kolaboratif. Perencanaan juga dapat dilakukan dengan cara: dibuat oleh salah seorang pendidik kemudian dikonsultasikan/dipaparkan dihadapan rekan pendidik yang lain sehingga mendapat saran dan masukan untuk memperoleh perencanaan pembelajaran yang baik. Tahap perencanaan bertujuan menghasilkan rancangan pembelajaran yang diyakini mampu secara efektif dan membangkitkan partisipasi (aktivitas) siswa dalam pembelajaran.

Tahap pelaksanaan (Do), tahap pelaksanaan ini dimaksudkan untuk menerapkan rancangan pembelajaran yang telah direncanakan. Dalam tahap Do seorang "pendidik (dosen) model" melakukan pembelajaran di kelas. Anggota kelompok melakukan observasi (terhadap aktivitas belajar semua peserta didik atau sesuai dengan tugas masing-masing). Setiap observer mencatat hasil observasi sebagai bahan refleksi. Jika memungkinkan dianjurkan untuk merekam kegiatan pembelajaran dengan handycam atau kamera. Pada tahap mengobservasi ini, setiap observer tidak boleh mengintervensi atau mengganggu peserta didik dalam proses pembelajaran. Harapannya, yaitu pembelajaran terjadi secara alami.

Tahap refleksi (see), Kegiatan refleksi dilakukan setelah kegiatan pembelajaran (do) selesai dilaksanakan, untuk melihat berbagai hal yang ditemukan dalam pelaksanaan pembelajaran, baik oleh pendidik (dosen) model maupun para observer. pendidik dan para observer melakukan sharing atas temuannya berkaitan dengan aktivitas belajar peserta didik selama proses pembelajaran. Observer dan pendidik (dosen) model saling belajar dari pembelajaran yang telah diamati dan hasil sharing digunakan untuk merivisi rencana pembelajaran dan sebagai masukan untuk pembelajaran pada pertemuan 
berikutnya. Tahap pengamatan dan refleksi (See) dimaksudkan untuk menemukan kelebihan dan kekurangan pelaksanaan pembelajaran. Pada tahapan ini dilakukan sebuah diskusi. Diskusi dilaksanakan secara formal (dipimpin oleh moderator dan disertai notulis). dosen model (pengajar) diberi kesempatan pertama untuk melakukan refleksi diri, tentang: perasaan dosen model sebelum, saat, dan setelah melaksanaan pembelajaran (open class); alur skenario atau langkah pembelajaran yang berhasil dan tidak berhasil dilaksanakan; Penilaian terhadap keberhasilan pembelajaran yang dilakukan.

Ketiga tahap dalam leson studi tersebut dilaksanakan pada dasarnya, yaitu untuk perbaikan pada pembelajaran berikutnya, begitu pun pada pembelajaran seterusnya. Tujuan pada masing-masing tahap lesson studi pada umumnya, yaitu mengamati aktivitas dari peserta didik dalam pembelajaran. Dalam pembelajaran apakah peserta didik dijadikan subjek atau objek. Hal ini sesuai dengan hakikat pembelajaran yaitu yang berpusat pada peserta didik.

Aktivitas belajar peserta didik adalah aktivitas yang bersifat fisik ataupun mental (Sardiman, 2005:96). Aktivitas belajar adalah serangkaian kegiatan fisik (jasmani) maupun mental (rohani) yang saling berkaitan sehingga tercipta belajar yang optimal. Dalam aktivitas belajar peserta didik haruslah aktif mendominasi dalam mengikuti proses belajar mengajar sehingga mengem- bangkan potensi yang ada pada dirinya. Dengan kata lain dalam beraktivitas peserta didik tidak hanya mendengarkan dan mencatat seperti yang dijumpai di Sekolah Dasar atau Sekolah Menengah yang melakukan pembelajaran secara konven- sional.

Diedrich (dalam Nasution, 2000:91) membuat suatu daftar yang berisi tentang macam kegiatan peserta didik yang dapat digolongkan sebagai berikut: 1) Visual activities, misalnya membaca, memperhatikan gambar, demonstrasi, percobaan, pekerjaan orang lain; 2) Oral activities, seperti menyatakan, merumuskan, bertanya, memberikan saran, mengeluarkan pendapat, mengadakan wawancara, diskusi, interupsi; 3) Listening activities, seperti mendengarkan penjelasan, percakapan, diskusi, musik, pidato; 4) Writing activities, seperti menulis cerita, karangan, laporan, angket, menyalin; 5) Drawing activities, misalnya meng- gambar, membuat grafik, peta, diagram, pola; 6) Motor activities, seperti melakukan percobaan, melakukan konstruksi, model, mereparasi, bermain; 7) Mental activities, misalnya menggali, mengingat, memecahkan soal, menganalisis, melihat hubungan, mengambil keputusan; dan 8) Emotional activities, misalnya menaruh minat, merasa bosan, gembira, bersemangat, bergairah, berani, tenang, gugup. Hasil belajar tidak hanya ditentukan oleh aktivitas peserta didik, tetapi aktivitas guru sangat diperlukan untuk merencanakan 
kegiatan peserta didik yang bervariasi. Dengan demikian, kondisi pembelajaran akan lebih dinamis dan tidak membosankan.

Kegiatan lesson study pada tahap perencanaan (plan), dosen model dan observer membahas tentang rencana pelaksanaan pembelajaran. Salah satu yang diamati pada tahap tersebut, yaitu keterlibatan peserta didik dalam pembelajaran tersebut. Saran dan masukan dari observer nantinya dicatat sebagai referensi pada tahap pelaksanaan (do) dan juga pada pembelajaran yang akan datang. Kemudian pada tahap pelakasanan $(d o)$, dosen model melaksanakan pembelajaran sesuai dengan pembelajaran yang telah direncanakan dan juga masukan dan saran dari observer yang diberikan pada tahap perencanaan (plan). Pada tahap ini observer mengamati aktivitas dari peserta didik ketika pelaksanaan pembelajaran. Pada tahap inilah observer dituntut untuk secara ekstra mengamati segala sesuatu aktivitas yang dilakukan oleh peserta didik. Hasil temuan dan pengamatan tersebut dicatat dan dijadikan sebagai bahan pada diskusi pada tahap selanjutnya, yaitu tahap refleksi (see).

Setelah tahap pelaksanaan selesai, kemudian dilanjutka pada tahap refleksi (see). Pada tahap ini dosen model memaparkan secara umum apa saja yang telah dilakukan, dan kekurangan-kekurangan yang dianggap pada tahap pelaksanaan. Kemudian dilanjutkan dengan pemaparan dari observer. Observer pada tahap ini hanya mengamati

aktivitas yang dilakukan dari peserta didik. Observer tidak mengomentari dari apa yang dilkukan oleh dosen model, sehingga fokus pengamatn hanya tertuju kepada peserta didik. Observer memaparka temuan-temuan yang terjadi pada tahap pelaksanaan. Temuan tersebut dapat berupa hal positif dan hal negatif (kekurangan dalam aktivitas peserta didik). Observer mengungkapkan pada tahap refleksi ini dan terjadilah diskusi pada tahap ini. Temuan tersebut dapat dijadikan masukan pada pembelajaran pada pertemuan berikutnya.

Pada tahap refleksi inilah aktivitas dari peserta didik dapat terlihat. Kegiatan leson studi berdampak sekali dalam kualitas pembelajaran yang berpusat pada pesera didik. Dalam pembelajaran yang telah direncanakan melalui lesson studi, peserta didik secara langsung akan ikut secara aktif dalam pembelajaran. Pada pertemuan pertama, awalnya terdapat kekurangan-ke kurangan. Namun, pada pertemuan berikutnya sesuai dengan masukan-masukan observer, pembelajaran selalu menitikberatkan pada aktivitas belajar dari peserta didik. Dengan demikian, secara langsung peserta didik akan secara aktif mengikuti pembelajaran yang telah dilaksanakan dan tujuan dari pembelajaran dapat tercapai. 


\section{PENUTUP}

Berdasarkan uraian yang telah dipaparkan, dapat ditarik kesimpulan antara lain: 1) kegiatan lesson studi merupakan model kegiatan pembinaan bagi para pendidik dalam memperbaiki pembelajaran di kelas; 2) dalam setiap tahapan lesson studi, pusat perhatian terdapat pada aktivitas peserta didik sehingga lesson studi merupakan kegiatan pembelajaran yang berpusat pada peserta didik; 3) melalui kegiatan lesson studi aktivitas belajar dari peserta didik tahap demi tahap akan terus meningkat sesuai dengan pembelajaran yang telah direncanakan. Dengan demikian, upaya meningkatkan aktivitas belajar dari peserta didik akan terwujud.

\section{DAFTAR RUJUKAN}

Hendayana, dkk. 2007. Lesson Study Suatu Strategi Untuk Meningkatakan Keprofesionalan Pendidik (Pengalaman IMSTEP-JICA). Bandung: UPI Press.

Nasution, S. 1997. Berbagai Pendekatan dalam Proses Belajar Mengajar. Jakarta: PT Bumi Aksara.

Rusman. 2014. Model-Model Pembelajaran Mengembangkan Profesionalisme Guru. Jakarta: Rajawali Pers.

Saito, E., Murase, M., Tsukui, A., Yeo, J. 2015. Lesson Study for Learning Community. New York: Routledge.

Sardiman. 2005. Interaksi dan Motivasi Belajar Mengajar. Jakarta: PT. Raja Grafindo Persada.

Slamet, Subad, T, Sutama, \& Khotimah,R.P. 2010. Peningkatan Kompetensi Guru Sekolah Dasar Melalui Lesson Study. Jurnal Warta, Vol .13, No.1, 55--64.

Susilo, H, Chotimah, H, Joharmawan, R, Jumiati, Dwita sari, Y, dan Sunarjo. 2009. Lesson Study Berbasis Sekolah. Malang: Bayumedia Publising. 